\title{
MJFAS MALAYSIAN JOURNAL OF

\section{In vitro shoot regeneration and analysis of biochemical, antioxidant and anticancer properties of Ananas comosus var. MD2}

\author{
Nur Asniyati Abdul Halim a , Sujatha Ramasamy a, Boon Chin Tan b, Norzulaani Khalid a,b, Jamilah \\ Syafawati Yaacob a,b,* \\ a Institute of Biological Sciences, Faculty of Science, University of Malaya, 50603 Kuala Lumpur, Malaysia \\ ${ }^{b}$ Centre for Research in Biotechnology for Agriculture (CEBAR), University of Malaya, 50603 Kuala Lumpur, Malaysia \\ *Corresponding author: jamilahsyafawati@um.edu.my
}

\section{Article history}

Submitted 9 November 2017

Revised 22 January 2018

Accepted 11 February 2018

Published Online 4 June 2018

\begin{abstract}
Pineapple (Ananas comosus (L.) Merr.) is one of the most important crops in the world. Although the phytochemical compounds of pineapple fruits have been extensively studied, little attention was paid on other parts of the plant. In this study, we developed an efficient in vitro regeneration procedures for $A$. comosus var. MD2 as well as analyzed the phytochemical composition, antioxidant and anticancer activities in field-grown and in vitro leaf samples. Leaf base explants cultured on Murashige and Skoog medium containing $1.0 \mathrm{mg} / \mathrm{L} \mathrm{IBA}$ and $2.0 \mathrm{mg} / \mathrm{L}$ BAP produced the highest frequency of microshoot induction (100\%) with D-leaf length to width ratio of 6.3 . Biochemical analysis showed that in vitro leaf samples contained higher amount of carotenoids and anthocyanins but lower total phenolic content and DPPH radical scavenging activity than field-grown leaves. Flavonoids, tannins, sterols and alkaloids were detected in both field-grown and in vitro leaf samples. The methanolic extracts from both samples exhibited low cytotoxic activity against human ovarian SKOV-3 and human breast MCF-7 cancer cells. These results suggested that pineapple leaves might not be suitable to serve as chemotherapeutic agent and further exploitation on other secondary metabolites is required.
\end{abstract}

Keywords: bioactivity, cytotoxicity, field-grown, in vitro, Ananas comosus

\section{INTRODUCTION}

Pineapple (Ananas comosus (L.) Merr.) is one of the most important crops worldwide (FAOSTAT 2015). Over 13 million metric tons of pineapple were harvested globally. In Malaysia, A. comosus variety MD2 has been listed as one of seven high-values and economically important crops under Malaysia's National Key Economic Areas (NKEA). MD2 is highly demanded in the international market due to its aroma, sugar and vitamin contents as well as its longer post-harvest shelf life. Conventionally, pineapple is propagated vegetatively through suckers. However, this method is slow and may take up to 8 years to generate propagules from single mother plants (Zuraida, Shahnadz et al. 2013). Moreover, it can easily transmit numerous diseases from old to new pineapple plantations. Therefore, an alternative method using plant tissue culture to mass produce disease-free pineapple plantlets in order to satisfy the increasing demand for pineapple fruits is essential.

Harvesting pineapple produces a large amount of waste material (Asim, Abdan et al. 2015). In 2008, about 384,673 metric tons of waste materials, such as leaves, were either burnt or discarded which can later cause pollution and landfill problems. Very small portions of pineapple leaf fibers are being used as feedstock and energy production (Asim, Abdan et al. 2015). Therefore, full utilization of these materials by amplifying industrial usage to minimize the wastage of renewable materials is vital. Instead of treating it as wastes, it is of great effort to evaluate its pharmacological properties for medicinal purposes.

Similar to many plant species, pineapple has many applications in folk medicines. Various parts of the pineapple plants have been used to treat numerous diseases and disorders. Apart from the fruit, stem, leaf, rhizome, root and latex of pineapple have been found to contain numerous medicinal properties. For instance, pineapple leaves have been traditionally used in Chinese medicine as anti-dyspepsia and anti-diarrheal agents (Song, Zhao et al. 2012). Other properties, such as anti-diabetic, anti-dyslipidemic and anti-oxidative, have also been reported (Xie, Xing et al. 2005), indicating its potential to serve as medicine. Besides being utilized as a traditional medicine, pineapple leaves are also used in textiles industry in the Philippines.

In this study, we aimed to mass propagate in vitro pineapple variety MD2 and to evaluate the chlorophyll content, total carotenoids, anthocyanin content, phytochemicals constituent, antioxidant activity and cytotoxicity of in vitro- and field grownpineapple leaves. This study might provide a new insight into the bioavailability of using pineapple waste material for a new health supplement.

\section{EXPERIMENTAL}

\section{Plant materials}

Leaf base of in vitro grown A. comosus var. MD2 initiated on Murashige and Skoog (MS) (Murashige and Skoog, 1962) medium supplemented with $1.0 \mathrm{mg} / \mathrm{L}$ NAA and $3 \mathrm{mg} / \mathrm{L}$ BAP (Hamid et al., 2013) were used as explants for shoot proliferation.

\section{Shoot proliferation and maintenance}

The leaf base explants (1 cm in length) were cultured on MS medium supplemented with different concentrations and combinations 
of indole-butyric acid (IBA; 0.0-2.0 mg/L) and 6-benzylaminopurine (BAP; 0.0-2.0 mg/L). All cultures were maintained at $25 \pm 1{ }^{\circ} \mathrm{C}$ under a photoperiod of $16 \mathrm{~h}$ light and $8 \mathrm{~h}$ dark with an illumination of 1000 lux. The frequency of microshoot induction, length and width of the D-leaf were measured after 8 weeks of culture.

\section{Preparation of methanolic extracts}

Leaves of in vitro plantlets and 2 month-old field grown (Fig. 1) plants collected from the Plant Biotechnology Research Centre (PPBGL), University of Malaya, Glami Lemi, Jelebu, Negeri Sembilan, Malaysia, were cleaned, freeze-dried (Labconco, USA) and ground into fine powder using a commercial blender before stored in airtight containers. Fine powder $(1 \mathrm{~g})$ were soaked in $30 \mathrm{~mL}$ absolute methanol for 7 days at $4{ }^{\circ} \mathrm{C}$ and filtered through a Whatman filter paper. Methanolic filtrate was subjected to pigment analysis and phytochemical analysis. For the phytochemical analysis, the methanolic filtrate was evaporated under reduced pressure (from 760 torr to 5 torr) at $60{ }^{\circ} \mathrm{C}$ using a rotary evaporator (Buchi Rotavapor R215, Switzerland). The concentrated methanolic extracts were dissolved in methanol to give stock solutions of $20 \mathrm{mg} / \mathrm{mL}$ and stored at $-20{ }^{\circ} \mathrm{C}$ freezer until further use.

\section{Determination of chlorophyll (Chl) and carotenoid contents}

The absorbance of the methanolic filtrate was measured using a UV-Vis spectrophotometer (Perkin Elmer ${ }^{\mathrm{TM}}$, USA) and the content of $\mathrm{Chl}$ ( $\mathrm{a}$ and $\mathrm{b}$ ) and total carotenoids $(666,653$ and $470 \mathrm{~nm}$ at which observed maximum absorbance were observed) were calculated according to (Lichtenthaler and Buschmann, 2001):

$\mathrm{C}_{\mathrm{a}}(\mu \mathrm{g} / \mathrm{mL})=16.72 \mathrm{~A}_{665.2}-9.16 \mathrm{~A}_{652.4}$

$\mathrm{Cb}_{\mathrm{b}}(\mu \mathrm{g} / \mathrm{mL})=34.09 \mathrm{~A}_{652.4}-15.28 \mathrm{~A}_{665.2}$

$\mathrm{C}_{(\mathrm{x}+\mathrm{c})}(\mu \mathrm{g} / \mathrm{mL})=\left(1000 \mathrm{~A}_{470}-1.63 \mathrm{C}_{\mathrm{a}}-104.96 \mathrm{C}_{\mathrm{b}}\right) / 221$

\section{Determination of anthocyanin content}

Total anthocyanin content was determined using $\mathrm{pH}$-differential method (Giusti and Wrolstad, 2001). The $\mathrm{pH}$ of the extract was adjusted to $\mathrm{pH} 1$ using $0.025 \mathrm{M}$ potassium chloride buffer and $\mathrm{pH} 4.5$ using $0.4 \mathrm{M}$ acetate buffer. The absorbance was measured at $510 \mathrm{~nm}$ and $700 \mathrm{~nm}$ using a Lambda $25 \mathrm{UV}-\mathrm{Vis}$ Spectrophtometer (Perkin Elmer $^{\mathrm{TM}}$, USA). The monomeric anthocyanin pigment concentration (cyanidin-3-glucoside) in the samples was calculated using formula described by (Giusti and Wrolstad, 2001).

Anthocyanin content $(\mathrm{mg} / \mathrm{L})=(\mathrm{A} \times \mathrm{MW} \times \mathrm{DF} \times 1000) /(\varepsilon \times 1)$

where,

$\mathrm{A}=\left(\mathrm{Abs}_{\lambda \text { vis-max }}-\mathrm{Abs}_{700}\right)_{\mathrm{pH} 1}-\left(\mathrm{Abs}_{\lambda \mathrm{vis}-\max }-\mathrm{Abs}_{700}\right)_{\mathrm{pH}} \mathrm{H} .5$

MW $($ cyanidin-3-glucoside $)=449$

$\mathrm{DF}=$ dilution factor

$\varepsilon$ (molar absorptivity of cyanidin-3-glucoside $)=26,900$

$\lambda_{\text {vis-max }}($ of cyanidin-3-glucoside in aqueous buffer at $\mathrm{pH} 1)=510 \mathrm{~nm}$

\section{Determination of total phenolic content}

Total phenolic content was determined according to (Folin and Ciocalteu, 1927). The methanolic extracts $(0.2 \mathrm{~mL})$ were pipetted into a $10.0 \mathrm{~mL}$ volumetric flask containing $4.0 \mathrm{~mL}$ water and $0.5 \mathrm{~mL}$ Folin-Ciocalteu's reagent. After $1 \mathrm{~min}, 2.0 \mathrm{~mL}$ of $20 \%$ aqueous solution of sodium carbonate were added to the mixture and made up to $10.0 \mathrm{~mL}$ with distilled water before incubated for $30 \mathrm{~min}$. Absorbance of total phenolics was measured at $760 \mathrm{~nm}$ and calculated from a calibrated curve $\left(r^{2}=0.9954\right)$ using gallic acid as standard $(0.001-0.006 \mathrm{mg} / \mathrm{mL})$. The results are expressed as gallic acid equivalent (mg GAE/g).

\section{Determination of DPPH free radical scavenging activity}

The free radical scavenging activity towards 1, 1-diphenyl-2picryl-hydrazil (DPPH) was assessed according to published method (Khalaf et al., 2008) with minor modifications. Briefly, about $10 \mathrm{~mL}$ of different concentrations $(10,50,100,200,300,500,700$ and 1000 $\mu \mathrm{g} / \mathrm{mL}$ ) of each extract were added to $1.0 \mathrm{~mL}$ of DPPH. An equal amount of ascorbic acid and DPPH was served as control. The mixture was mixed and incubated at room temperature in the dark for $30 \mathrm{~min}$. Absorbance was measured at $517 \mathrm{~nm}$ and the DPPH radical scavenging activity was calculated according to the following formula (Gawron-Gzella et al., 2012, Khalaf et al., 2008).

DPPH scavenging activity $(\%)=\left[\left(\mathrm{A}_{0}-\mathrm{A}_{1}\right) / \mathrm{A}_{0}\right] \times 100$

where,

$\mathrm{A}_{0}=$ absorbance of control

$\mathrm{A}_{1}=$ absorbance of sample

The percentage of DPPH radical scavenging activity against concentration was plotted by performing non-linear regression (third degree polynomial) as previously described (Abourashed, 2005, Samarakoon et al., 2011). The results were interpreted as $50 \%$ inhibition concentration ( $\mathrm{IC}_{50}$ ) in $\mu \mathrm{g} / \mathrm{mL}$.

\section{Determination of ferric reducing antioxidant power (FRAP)}

FRAP assay was performed based on the method described by Benzie et al. (Benzie \& Strain, 1999) with slight modifications. About $300 \mu \mathrm{L}$ extracts or methanol (control) were mixed with $10 \mu \mathrm{L}$ FRAP reagent and incubated in microplate wells at room temperature in the dark for $30 \mathrm{~min}$. The absorbance was recorded at $593 \mathrm{~nm}$. A series of stock solution at 100, 10, 1, 0.1 and $0.01 \mathrm{mM}$ of aqueous ascorbic acid were prepared to generate a standard curve $\left(r^{2}=0.9944\right)$. The results obtained were expressed as $\mathrm{mM}$ of ascorbic acid equivalent per gram of dried sample

\section{Analysis of phytochemical compounds}

Phytochemical compounds were analyzed as previously described (Solihah et al., 2012) with slight modifications:

\section{Test for phenols}

Methanolic extract $(2 \mathrm{~mL})$ was warmed at $45-50{ }^{\circ} \mathrm{C}$ before adding $2 \mathrm{~mL}$ of $3 \%(\mathrm{w} / \mathrm{v})$ of $\mathrm{FeCl}_{3}$. Formation of green or blue color indicates the presence of phenols.

\section{Test for flavonoids (I)}

Methanolic extract $(1 \mathrm{~mL})$ was added to $1 \mathrm{~mL}$ of $10 \%$ $\left(\mathrm{CH}_{3} \mathrm{COO}_{2}\right)_{2} \mathrm{~Pb} \quad(\mathrm{w} / \mathrm{v})$ and gently shaken. A muddy brownish precipitate indicates the presence of flavonoids.

\section{Test for flavonoids (II)}

One (1) $\mathrm{mL}$ methanolic extract was added to $10 \% \mathrm{FeCl}_{3}(\mathrm{w} / \mathrm{v})$ and gently shaken. A wooly brownish precipitate indicates the presence of flavonoids.

\section{Test for tannins}

One (1) $\mathrm{mL}$ methanolic extract was added to $1 \mathrm{~mL}$ of $3 \%$ (w/v) of $\mathrm{FeCl}_{3}$. A greenish black precipitate signifies the presence of tannins.

\section{Test for phlobatannins}

One (1) $\mathrm{mL}$ methanolic extract was boiled with $2 \mathrm{~mL} 1 \%(\mathrm{v} / \mathrm{v})$ $\mathrm{HCl}$. The formation of red precipitate signifies the presence of phlobatannins.

\section{Test for alkaloids}

Methanolic extract $(1 \mathrm{~mL})$ was stirred with $5 \mathrm{~mL}$ of $1 \%(\mathrm{v} / \mathrm{v})$ $\mathrm{HCL}$ on a steam bath $\left(60{ }^{\circ} \mathrm{C}\right)$ for $15 \mathrm{~min}$ and filtered. Test for alkaloids I: $1 \mathrm{~mL}$ of Dragendorff reagent was added to $1 \mathrm{~mL}$ methanolic filtrate. The formation of cloudy orange indicates the presence of alkaloids. Test for alkaloids II: $1 \mathrm{~mL}$ of Mayer reagent was added to $1 \mathrm{~mL}$ of filtrate. Appearance of slight yellow color indicates the presence of alkaloids. Test for alkaloids III: $1 \mathrm{~mL}$ of Wagner reagent was added to $1 \mathrm{~mL}$ of filtrate. The formation of turbid brown color indicates the presence of alkaloids.

\section{Test for terpenoids}

A total of $5 \mathrm{~mL}$ methanolic extract was mixed with $2 \mathrm{~mL} \mathrm{CHCl}_{3}$ before adding $3 \mathrm{~mL}$ concentrated $\mathrm{H}_{2} \mathrm{SO}_{4}$. Formation of the reddish 
brown coloration between upper and lower layer indicates the presence of terpenoids.

\section{Test for saponins}

Approximately $0.2 \mathrm{~mL}$ methanolic extract was mixed with $5 \mathrm{~mL}$ distilled water and shaken vigorously for $5 \mathrm{~min}$. Persistence of foams appearance is the indicator for saponins.

\section{Test for sterols (Salkowski's test)}

Two (2) $\mathrm{mL}$ of concentrated $\mathrm{H}_{2} \mathrm{SO}_{4}$ was added to $2 \mathrm{~mL}$ methanolic extract. A red precipitate formation indicates the presence of steroidal ring compound(s) in the sample.

\section{Test for xanthoprotein}

A few drops of $\mathrm{HNO}_{3}$ were added by the side of the test tube containing $1 \mathrm{~mL}$ methanolic extract. A yellow color is formed indicates the presence of xanthoprotein.

\section{Test for cardiac-glycosides}

Methanolic extract $(100 \mathrm{mg})$ was dissolved in $1 \mathrm{~mL}$ of $\mathrm{CH}_{3} \mathrm{COOH}$ containing 1 drop of $3 \%(\mathrm{w} / \mathrm{v}) \mathrm{FeCl}_{3}$. One (1) $\mathrm{mL}$ of concentrated $\mathrm{H}_{2} \mathrm{SO}_{4}$ was then slowly added to the mixture. The formation of brown ring at the interface indicates the presence of de-oxy sugar characteristics of cardenolides compound(s).

\section{Neutral red (NR) uptake assay}

The cytotoxicity was measured by Neutral Red Uptake assay based on the uptake and subsequent lysosomal accumulation of the supravital dye, neutral red, in viable and uninjured cancer cells. Human ovarian SKOV-3 and breast MCF-7 cancer cell lines detached from conical flasks with $1.0 \mathrm{~mL}$ solution of accutase in phosphate buffer solution, $\mathrm{pH} 7.4$ were centrifuged at $120 \times \mathrm{g}$ for $5 \mathrm{~min}$. Viable cells was counted by $0.4 \%(\mathrm{w} / \mathrm{v})$ of trypan blue exclusion method using a haemocytometer (Marienfield, Germany) as described by (Freshney, 1994). The cells were seeded in a 96 well micro titer plate (Nunc, China) at a concentration of $30000 \mathrm{cells} / \mathrm{mL}$ and incubated at $37{ }^{\circ} \mathrm{C}$ for $3 \mathrm{~h}$ in a humidified $5 \% \mathrm{CO}_{2} / 95 \%$ air incubator. After incubation, the dye-containing medium was discarded and six different concentrations of extracts $(1,10,25,50,75$ and $100 \mu \mathrm{g} / \mathrm{mL})$ were added. Untreated cells under the same conditions were used as controls. The plates were incubated at $37{ }^{\circ} \mathrm{C}$ for $72 \mathrm{~h}$. The plates were re-incubated at room temperature for $3 \mathrm{~h}$ in medium containing 50 $\mu \mathrm{g} / \mathrm{mL}$ NR solution and cells were subsequently washed with a mixture of calcium chloride: formaldehyde in distilled water (1:10:89, $\mathrm{v} / \mathrm{v} / \mathrm{v}$ ) solution to remove NR solution (Ramasamy et al., 2013). The incorporated dye was solubilized using $1 \%$ acetic acid and $50 \%$ ethanol in milli-Q water $(0.2 \mathrm{~mL})$. The plates were agitated on a micro titer plate shaker (LT BioMax 500) for $30 \mathrm{~min}$.
The extracted dye absorbance was measured at $540 \mathrm{~nm}$ using a microplate reader (Emax, Molecular Devices USA). Three independent experiments were performed for each extract. NR uptake, proportional to the number of viable cells within the well, was expressed as a percentage of NR uptake by control cells, arbitrarily set to $100 \%$ :

NR uptake $(\%)=\left[\left(\mathrm{OD}_{\text {cont }}-\mathrm{OD}_{\text {samp }}\right) / \mathrm{OD}_{\text {cont }}\right] \times 100$

*cont: control, samp: sample

\section{Statistical analysis}

All experiments were carried out in triplicates following a randomized complete block design (RCBD). Data were statistically analyzed by one-way analysis of variance (ANOVA) and Duncan's multiple range test (DMRT) at 5\% significance level using SPSS version 22. All results were reported as mean \pm SE of three replicated experiments.

\section{RESULTS AND DISCUSSION}

\section{Shoot induction and proliferation of $\boldsymbol{A}$. comosus}

Leaf base explants demonstrated differential responses on the different concentrations of plant growth regulators in the culture media after one week of culture. The highest frequency of microshoot induction $(100 \%)$ was recorded on the medium containing $1.0 \mathrm{mg} / \mathrm{L}$ IBA and $2.0 \mathrm{mg} / \mathrm{L}$ BAP (Fig. 1a). The medium containing low concentrations of BAP $(0.5 \mathrm{mg} / \mathrm{L})$ alone was found to promote shoot elongation and number of leaves per shoot (data not shown) with Dleaf width of $1 \mathrm{~cm}$ (Table 1). BAP has been considered as one of the most effective cytokinins for shoot induction and regeneration (Tan et al., 2011).

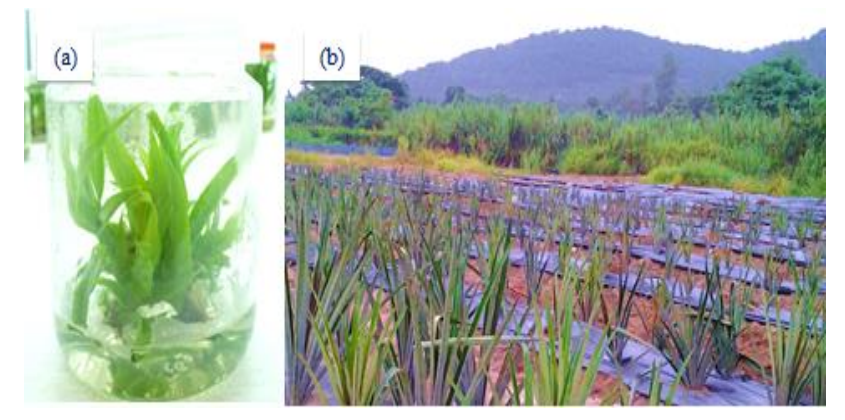

Fig. 1 In vitro and field-grown pineapple plants (a) Proliferation of multiple shoots from leaf base explants after 2 months of culture (b) 2 month-old field-grown plants.

Table 1 Effects of different concentrations and combinations of plant growth regulators on frequency of microshoot induction, length of D-leaf, width of D-leaf and D-leaf size (length to width ratio).

\begin{tabular}{ccccc}
\hline $\begin{array}{c}\text { Plant growth regulator } \\
(\mathbf{m g} / \mathbf{L})\end{array}$ & $\begin{array}{c}\text { Frequency of microshoot } \\
\text { induction }(\%)\end{array}$ & $\begin{array}{c}\text { Length of D-leaf } \\
(\mathbf{c m})\end{array}$ & $\begin{array}{c}\text { Width of D-leaf } \\
(\mathbf{c m})\end{array}$ & $\begin{array}{c}\text { D-leaf size (length to } \\
\text { width ratio) }\end{array}$ \\
\hline Control (MS basal) & $73.3 \pm 3.3^{\mathrm{ef}}$ & $5.1 \pm 0.3^{\mathrm{c}}$ & $0.5 \pm 0.0^{\mathrm{ab}}$ & 10.2 \\
\hline $1.0 \mathrm{IBA}$ & $46.7 \pm 3.3^{\mathrm{bc}}$ & $5.3 \pm 0.2^{\mathrm{c}}$ & $0.6 \pm 0.0^{\mathrm{ab}}$ & 8.8 \\
\hline $2.0 \mathrm{IBA}$ & $43.3 \pm 3.3^{\mathrm{ab}}$ & $5.2 \pm 0.2^{\mathrm{c}}$ & $0.6 \pm 0.0^{\mathrm{bc}}$ & 8.6 \\
\hline $0.5 \mathrm{BAP}$ & $80.0 \pm 0.0^{\mathrm{fg}}$ & $7.5 \pm 0.3^{\mathrm{f}}$ & $1.0 \pm 0.0^{\mathrm{f}}$ & 7.5 \\
\hline $1.0 \mathrm{BAP}$ & $66.7 \pm 3.3^{\mathrm{de}}$ & $5.0 \pm 0.2^{\mathrm{c}}$ & $0.8 \pm 0.0^{\mathrm{e}}$ & 6.3 \\
\hline $2.0 \mathrm{BAP}$ & $70.0 \pm 5.8^{\mathrm{ef}}$ & $4.8 \pm 0.6^{\mathrm{c}}$ & $0.8 \pm 0.0^{\mathrm{e}}$ & 6.0 \\
\hline $1.0 \mathrm{IBA}+0.5 \mathrm{BAP}$ & $86.7 \pm 3.3^{\mathrm{g}}$ & $6.4 \pm 0.2^{\mathrm{e}}$ & $0.8 \pm 0.0^{\mathrm{e}}$ & 8.0 \\
\hline $2.0 \mathrm{IBA}+0.5 \mathrm{BAP}$ & $66.7 \pm 3.3^{\mathrm{de}}$ & $5.4 \pm 0.1^{\mathrm{d}}$ & $0.7 \pm 0.0^{\mathrm{de}}$ & 7.7 \\
\hline $1.0 \mathrm{IBA}+1.0 \mathrm{BAP}$ & $56.7 \pm 3.3^{\mathrm{cd}}$ & $5.0 \pm 0.1^{\mathrm{c}}$ & $0.7 \pm 0.0^{\mathrm{e}}$ & 7.1 \\
\hline $2.0 \mathrm{IBA}+1.0 \mathrm{BAP}$ & $46.7 \pm 3.3^{\mathrm{bc}}$ & $4.2 \pm 0.1^{\mathrm{b}}$ & $0.5 \pm 0.0^{\mathrm{ab}}$ & 8.4 \\
\hline $1.0 \mathrm{IBA}+2.0 \mathrm{BAP}$ & $100.0 \pm 0.0^{\mathrm{h}}$ & $5.0 \pm 0.2^{\mathrm{c}}$ & $0.8 \pm 0.1^{\mathrm{e}}$ & 6.3 \\
\hline $2.0 \mathrm{IBA}+2.0 \mathrm{BAP}$ & $43.3 \pm 3.3 \mathrm{~b}^{\mathrm{ab}}$ & $3.5 \pm 0.1^{\mathrm{a}}$ & $0.5 \pm 0.0^{\mathrm{a}}$ & 7.0 \\
\hline
\end{tabular}

Data represent mean value \pm standard error (SE) with 30 explants in each treatment. Means with different letters in the same column are significantly different at $p<0.05$ according to ANOVA and Duncan's multiple range test (DMRT). 
Similar to our findings, Zuraida et al. (Zuraida et al., 2013) reported that MS medium supplemented with 1.0 or $5.0 \mathrm{mg} / \mathrm{L}$ BAP was able to produce the highest number of shoots for A. comosus var. Maspine. The authors indicated that supplementation of BAP alone in culture medium was sufficient to produce shoot multiplication. This was in agreement with previous report (Kiss et al., 1995), where incorporation of NAA in culture medium is not necessary for pineapple in vitro shoot multiplication. Continuous application of NAA might cause detrimental effects to growth and multiplication of pineapple (Wakasa, 1989). Taken together, MS medium supplemented with $1.0 \mathrm{mg} / \mathrm{L} \mathrm{IBA}$ and $2.0 \mathrm{mg} / \mathrm{L} \mathrm{BAP}$ was selected for subsequent shoot multiplication.

\section{Distribution of $\mathrm{Chl}$ and carotenoids}

The chlorophyll and carotenoid contents for the leaves of fieldgrown and in vitro A. comosus var. MD2 were investigated. The amounts of $\mathrm{Chl}(a$ and $b$ ) and carotenoids in in vitro leaf samples were at least 10 -fold higher than field-grown samples with $\mathrm{Chl} \mathrm{a} / \mathrm{b}$ ratio of 0.21 (Table 2). Differences of Chl amounts between field-grown and in vitro samples might be due to edaphic and climatic factors, such as light, water stress and salt stress (Sevik et al., 2012). Chl a/b ratio was low when compared to $\mathrm{C} 3$ plants $(\mathrm{Chl} \mathrm{a} / \mathrm{b}$ ratio of 2.5-3.5). Typically, shade plants have lower $\mathrm{Chl} \mathrm{a} / \mathrm{b}$ ratio than sun-exposed plants as shade plants containing more light-harvesting protein LHC-II in photosystem II (PSII) than sun-exposed plants (Lichtenthaler and Buschmann, 2001). Leaves exposed to- and shaded from- sun light are differ in internal and external structures and photosynthetic rate, probably due to the amount of active ray received (Kurtar, 2012). Direct sun light may contain about $35 \%$ of active ray that can penetrate leaves, whereas diffuse light may have $50-60 \%$ of active ray (Kurtar, 2012).

In terms of carotenoid contents, in vitro leaves were 11.8 -fold higher than field-grown leaves (Table 2). Carotenoids are essential for photoprotection in photosynthetic plant tissues and their levels are influenced by several factors, including plant species and organs, production practice, maturity as well as environmental growth factors, such as light, temperature and soil properties (Van den Berg et al., 2000). For instance, it has been reported that the carotenoid content in tomato fruits was higher than leaves (Perrin et al., 2016). They also reported carrot roots showed higher carotenoid content than leaves.

Table 2 Chlorophyll, total carotenoid and pigment contents ( $\mathrm{mg} / \mathrm{g}$ dry weight) of field-grown and in vitro A. comosus var. MD2 leaves.

\begin{tabular}{|c|c|c|c|c|c|c|c|}
\hline \multirow[b]{2}{*}{ Sample } & & \multicolumn{6}{|c|}{ Pigment content (mg/g dry weight) } \\
\hline & $\mathrm{C}_{\mathrm{a}}$ & $\mathrm{C}_{\mathrm{b}}$ & $\mathrm{C}_{\mathrm{a}}+\mathrm{C}_{\mathrm{b}}$ & $C_{(x+c)}$ & $\mathrm{C}_{\mathrm{a}} / \mathrm{C}_{\mathrm{b}}$ ratio & $\begin{array}{c}\mathrm{C}_{a}+\underset{\text { ratio }}{\mathrm{C}_{\mathrm{b}} / \mathrm{C}_{(\mathrm{x}+\mathrm{c})}} \\
\end{array}$ & Total \\
\hline $\begin{array}{l}\text { Field- } \\
\text { grown }\end{array}$ & $0.03 \pm 0.00^{\mathrm{a}}$ & $0.16 \pm 0.00^{\mathrm{a}}$ & $0.19 \pm 0.00^{\mathrm{a}}$ & $0.07 \pm 0.00^{\mathrm{a}}$ & $0.18 \pm 0.00^{a}$ & $2.74 \pm 0.00^{\mathrm{b}}$ & $0.26 \pm 0.00^{\mathrm{a}}$ \\
\hline In vitro & $0.38 \pm 0.00^{\mathrm{b}}$ & $1.83 \pm 0.00^{\mathrm{b}}$ & $2.21 \pm 0.00^{b}$ & $0.83 \pm 0.00^{b}$ & $0.21 \pm 0.00^{\mathrm{b}}$ & $2.66 \pm 0.00^{\mathrm{a}}$ & $3.04 \pm 0.00^{b}$ \\
\hline
\end{tabular}

${ }^{*} C_{a}$ chlorophyll $a, C_{b}$ chlorophyll $b, C_{a}+C_{b}$ total chlorophyll $a$ and $b, C_{(x+c)}$ total carotenoid (xanthophyll and carotene).

\section{Distribution of anthocyanin content}

Similar to Chl content, the content of anthocyanin for in vitro leaf extracts $(3.16 \mathrm{mg} / \mathrm{g})$ was also significantly $(p<0.05)$ higher than fieldgrown $(1.35 \mathrm{mg} / \mathrm{g})$ (Table 3$)$. Anthocyanins are common flavonoids which are found ubiquitously in many plants. They show bright redorange to blue-violet color in various fruits and vegetable-based food products (Wallace, 2011). Anthocyanins reversibly change color with $\mathrm{pH}$ which limits their effectiveness as food colorants for many applications, but they provide an easy and convenient way for measuring total pigment concentration (Giusti and Wrolstad, 2001).

Anthocyanin content has been known to be correlated with Chl content (Gitelson et al., 2001). Its content is often affected by $\mathrm{pH}$, temperature, light, presence of co pigments, self-association, metallic ions, enzymes, oxygen, ascorbic acid, sugar and their degradation products, protein and sulfur dioxide (Sahari et al., 2004). Low amount of anthocyanins in field-grown samples might be due to the degradation of these compounds by natural environmental conditions since anthocyanin is an unstable compound (Jiang, 2000). Previous study also showed that anthocyanins in pineapple was low and only found on fruits (Pavan et al., 2012). Other plant species, such as banana, asparagus, pea, fennel, pear and potato, also exhibited less amount of anthocyanins and probably absent in some species such as green gooseberries (Wu et al., 2004).

Table 3 Anthocyanin content of methanolic leaf extracts of field-grown and in vitro $A$. comosus var. MD2.

\begin{tabular}{ccc}
\hline Sample & $\begin{array}{c}\text { Absorbance maximum } \\
\text { at pH 1, } \mathbf{A}_{\max }\end{array}$ & $\begin{array}{c}\text { Monomeric anthocyanin } \\
\text { pigment content }(\mathbf{m g} / \mathbf{g})\end{array}$ \\
\hline $\begin{array}{c}\text { Field- } \\
\text { grown }\end{array}$ & 0.036 & $1.35^{\mathrm{a}}$ \\
In vitro & 0.084 & $3.16^{\mathrm{b}}$ \\
\hline
\end{tabular}

Means with different letters within the same column are significantly different at $p<0.05$ according to ANOVA and Duncan's multiple range test (DMRT).

\section{Measurement of total phenolic content}

The total phenolic content for in vitro leaves $(0.296 \mathrm{mg} / \mathrm{g} \mathrm{GAE})$ were significantly $(p<0.05)$ lower than field-grown plants $(0.433 \mathrm{mg} / \mathrm{g}$ GAE) (Table 4). One of the possibilities for this might be due to the influence of light intensity. The field-grown plants may receive higher light intensity (30,000 to 100,000 lux) compared to in vitro plants (approximately 1,000 lux) which may induce higher amount of phenolic contents (Colonna et al., 2016). Phenolic compounds are very important plant constituents due to their hydroxyl groups that can confer scavenging activity on free radicals constituents and reactive oxygen species (Hatano et al., 1989, Prior and Cao, 2000). In plants, different organs exhibit different amount of phenolic compounds. For instance, total phenolic content of pineapple fruits $(40.4 \mathrm{mg} / \mathrm{g})$ was found to be higher than field-grown $(1.3 \mathrm{mg} / \mathrm{g}$ ) leaves (Upadhyay et al., 2013). Other parts, such a pulp, seeds and peels, recorded $10 \mathrm{mg} / \mathrm{g}$ of GAE, suggesting that the sequence order of phenolic contents for these organs are fruits $>$ pulp/seeds/peels $>$ leaves.

Table 4 Total phenolic content of methanolic leaf extracts of field-grown and in vitro $A$. comosus var. MD2.

\begin{tabular}{cc}
\hline Sample & $\begin{array}{c}\text { Total phenolic content } \\
\text { (mg GAE per g of extract) }\end{array}$ \\
\hline Field-grown & $0.433^{\mathrm{b}}$ \\
In vitro & $0.296^{\mathrm{a}}$
\end{tabular}

Means with different letters within the same column are significantly different at $p<0.05$ according to ANOVA and Duncan's multiple range test (DMRT).

\section{Analysis of DPPH free radical scavenging activity}

Both field-grown and in vitro leaf samples had lower DPPH radical scavenging activity than ascorbic acid (Figure 2). The DPPH radical scavenging activity was dose-dependent, whereby the DPPH scavenging activity increased proportionally with the increased concentration of the extracts. Field-grown leaf extracts had significantly lower $\mathrm{IC}_{50}$ value than in vitro samples (Table 5). It has been reported that there are a strong correlation between antioxidant activities and total phenolic compounds (de Oliveira et al., 2009, Bertoncelj et al., 2007). Since pineapple leaves contained less phenolic compounds, the DPPH scavenging efficiency was also low. Furthermore, numerous vital phenolic compounds, such as gallic acid, ferulic acid, rutin, quercetin, and apigenin, which contribute to high DPPH scavenging activity (Can et al., 2015) were not detected in our study. 


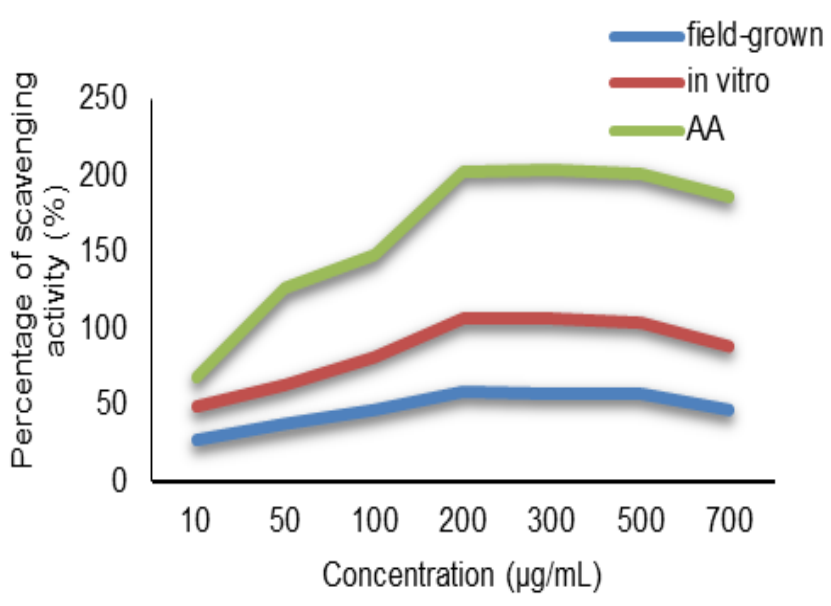

Fig. 2 DPPH free radical scavenging activity of field-grown and in vitro A. comosus var. MD2 leaves.

${ }^{*} A A$ ascorbic acid.

Table 5 DPPH Free radical scavenging activity and $\mathrm{IC}_{50}$ of field-grown and in vitro grown $A$. comosus var. MD2 leaves.

\begin{tabular}{ccc}
\hline Sample & $\begin{array}{c}\text { Percentage of } \\
\text { inhibition at 200 } \\
\boldsymbol{\mu g} / \mathbf{m L}\end{array}$ & $\begin{array}{c}\mathrm{IC}_{50} \text { values } \\
(\boldsymbol{\mu g} / \mathbf{m L})\end{array}$ \\
\hline Ascorbic acid & 71.07 & 17.07 \\
Field-grown & 45.06 & 38.15 \\
in vitro & 36.22 & 41.30
\end{tabular}

Means with different letters within the same column are significantly different at $p<0.05$ according to Duncan's multiple range test (DMRT).

\section{Analysis of ferric reducing capacity}

The ferric reducing potential of a compound indicates its "antioxidant power". The dose response curve for the reducing power of field-grown and in vitro leaf samples was compared to the standard (ascorbic acid). Both field-grown and in vitro leaf extracts were found to have lower FRAP activity than ascorbic acid (Table 6). Similar to DPPH activity, the total ferric reducing activities is also correlated with total phenolic contents and DPPH radical scavenging activities (Can et al., 2015) With low amount of phenolic compounds in the samples, DPPH radical scavenging and FRAP activities were also found to be low (Borges et al., 2009).

Table 6 FRAP $\left(\mathrm{mM} \mathrm{Fe}^{2+} / \mathrm{g}\right)$ values of field-grown and in vitro $A$. comosus var. MD2 leaves.

\begin{tabular}{cc}
\hline Sample & FRAP $\left(\mathrm{mM} \mathrm{Fe}^{2+} / \mathbf{g}\right)$ \\
\hline Ascorbic acid (standard) & $0.2014^{\mathrm{c}}$ \\
Field-grown & $0.0012^{\mathrm{a}}$ \\
in vitro & $0.0083^{\mathrm{b}}$ \\
\hline
\end{tabular}

Means with different letters within the same column are significantly different at $p<0.05$ according to ANOVA and Duncan's multiple range test (DMRT).

\section{Analysis of phytochemical compounds}

The presence of various phytochemical constituents in A. comosus var. MD2 leaves was analyzed. The phytochemical analysis showed that flavonoids, tannins, sterols and alkaloids were present in both field-grown and in vitro leaf extracts (Table 7). Similar to the study carried out by (Upadhyay et al., 2013) the present study also detected sterol in the pineapple leaves but no other important organic compounds, such as phlobatannins, terpenoids, sterols, glycosides, saponins and xanthoproteins. Other organic compounds, namely saponins, diterpenes, triterpenes and antraquinones, have also not been detected in pineapple leaves (Subramanian et al., 2014).
Table 7 Analysis of phytochemical constituents of field-grown and in vitro A. comosus var. MD2 leaves.

\begin{tabular}{ccc}
\hline Phytoconstituents & Field-grown & In vitro \\
\hline Phenols & - & - \\
Flavonoids (I) & + & + \\
Flavonoids (II) & + & + \\
Tannins & + & + \\
Phlobatannins & - & - \\
Alkaloids I & + & + \\
Alkaloids II & + & + \\
Alkaloids III & + & + \\
Terpenoids & - & - \\
Saponins & - & - \\
Sterols & + & + \\
Protein - xanthoprotein & - & - \\
Cardiac glycosides & - & \\
\hline${ }^{*}$ present, - absent & &
\end{tabular}

\section{Determination of cytotoxicity effect on SKOV-3 and MCF-7 cells}

In this study, the methanolic extract of field-grown and in vitro A. comosus var. MD2 leaves were investigated for their cytotoxic effects on human ovarian SKOV-3 and breast MCF-7 cancer cell lines. In general, both field-grown and in vitro leaf extracts showed low cytotoxic activity ( $<50 \%$ inhibition) against both SKOV-3 and MCF7 cancer cells (Figure 3), probably due to the low amount of bioactive compounds in pineapple leaves.
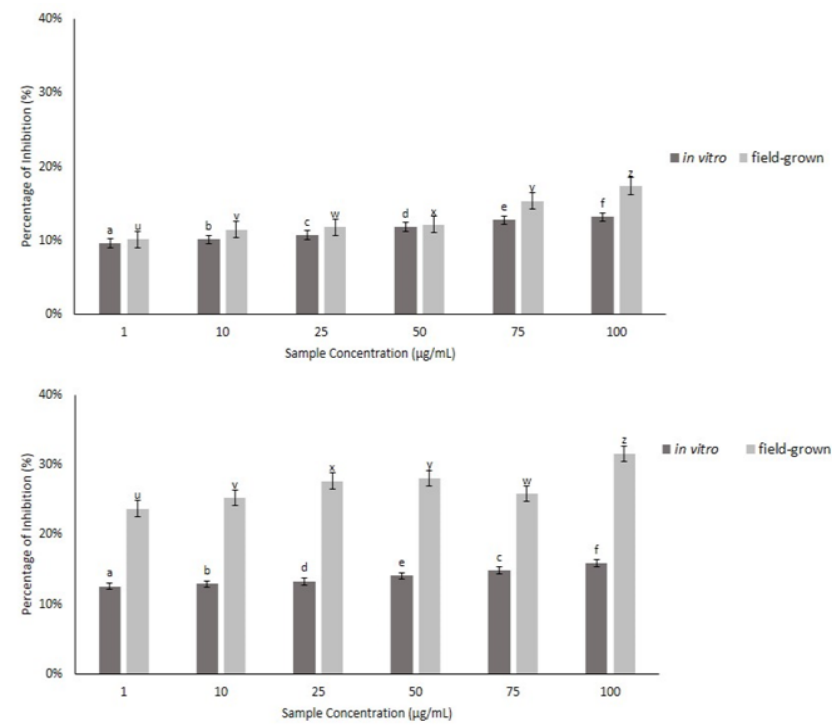

Fig. 3 Cytotoxic effect of field-grown and in vitro grown $A$. comosus var. MD2 leaf samples towards human breast MCF-7 cancer cell line (top); Cytotoxic effect of field-grown and in vitro gro wn A. comosus var. MD2 leaf samples towards human ovarian SKOV-3 cancer cell line (bottom).

\section{CONCLUSION}

The extracts of pineapple leaves (field-grown and in vitro) displayed weak radical scavenging activities, low reducing power and were less effective to inhibit human breast cancer MCF-7 and human ovarian cancer SKOV-3 cell proliferations. Our findings suggested that the pineapple leaves might not be suitable to serve as chemotherapeutic agent and further exploitation on other secondary metabolites is required. 


\section{ACKNOWLEDGEMENT}

The authors thank the University of Malaya, Malaysia, for providing experimental facilities and financial support (UMRG grant RP015B-14AFR and PPP grant PG117-2015A), as well as Ministry of Higher Education, Malaysia for FRGS Grant No. FP041-2014A.

\section{REFERENCES}

Abourashed, E.A. (2005), "Thin-layer densitometry as an alternative tool in the quantitative evaluation of the free radical scavenging activity of natural antioxidants", Zeitschrift Fur Naturforschung Section B: A Journal of Chemical Sciences, Vol. 60 No. 11, pp. 1212-8.

Bertoncelj, J., Dobersek, U., Jamnik, M. and Golob, T. (2007), "Evaluation of the phenolic content, antioxidant activity and colour of Slovenian honey", Food Chemistry, Vol. 105 No. 2, pp. 822-8.

Borges, G., Degeneve, A., Mullen, W. and Crozier, A. (2009), "Identification of flavonoid and phenolic antioxidants in black currants, blueberries, raspberries, red currants, and cranberries $\dagger "$, Journal of Agricultural and Food Chemistry, Vol. 58 No. 7, pp. 3901-9.

Can, Z., Yildiz, O., Sahin, H., Akyuz Turumtay, E., Silici, S. and Kolayli, S. (2015), "An investigation of Turkish honeys: Their physico-chemical properties, antioxidant capacities and phenolic profiles", Food Chemistry, Vol. 180 pp. 133-41.

Colonna, E., Rouphael, Y., Barbieri, G. and De Pascale, S. (2016), "Nutritional quality of ten leafy vegetables harvested at two light intensities", Food Chemistry, Vol. 199 pp. 702-10.

de Oliveira, A.C., Valentim, I.B., Silva, C.A., Bechara, E.J.H., de Barros, M.P., Mano, C.M. and Goulart, M.O.F. (2009), "Total phenolic content and free radical scavenging activities of methanolic extract powders of tropical fruit residues", Food Chemistry, Vol. 115 No. 2, pp. 469-75.

Folin, O. and Ciocalteu, V. (1927), "On tyrosine and tryptophane determinations in proteins", Journal of Biological Chemistry, Vol. 73 No. 2, pp. 627-50.

Freshney, R. (1994), "Measurement of viability and cytotoxicity", Culture of animal cells. Wiley-Liss, New York, pp. 296-8.

Gawron-Gzella, A., Dudek-Makuch, M. and Matławska, I. (2012), "DPPH radical scavenging activity and phenolic compound content in different leaf extracts from selected blackberry species", Acta Biologica Cracoviensia Series Botanica, Vol. 54 No. 2, pp. 32-8.

Gitelson, A.A., Merzlyak, M.N. and Chivkunova, O.B. (2001), "Optical properties and nondestructive estimation of anthocyanin content in plant leaves", Photochemistry and photobiology, Vol. 74 No. 1, pp. 38-45.

Giusti, M.M. and Wrolstad, R.E. (2001), "Characterization and measurement of anthocyanins by UV-visible spectroscopy", Current Protocols in Food Analytical Chemistry, John Wiley and Sons, USA.

Hamid, N., Bukhori, M. and Jalil, M. (2013), "Direct and indirect plant regenerations of pineapple var. MD2 Ananas comosus L.)", Malaysian Applied Biology, Vol. 42 No. 1, pp. 61-6.

Hatano, T., Fukuchi, K., Sakagami, H., Okuda, T., Tanuma, S.-i., Kitajima, K., Inoue, Y., Inoue, S., Ichikawa, S. and Nonoyama, M. (1989), "Inhibition of herpes simplex virus infection by tannins and related compounds", Antiviral Research, Vol. 11 No. 5, pp. 285-97.

Jiang, Y. (2000), "Role of anthocyanins, polyphenol oxidase and phenols in lychee pericarp browning", Journal of the Science of Food and Agriculture, Vol. 80 No. 3, pp. 305-10.

Khalaf, N.A., Shakya, A.K., Al-Othman, A., El-Agbar, Z. and Farah, H. (2008), "Antioxidant activity of some common plants", Turkish Journal of Biology, Vol. 32 No. 1, pp. 51-5.

Kiss, E., Kiss, J., Gyulai, G. and Heszky, L. (1995), "A novel method for rapid micropropagation of pineapple", HortScience, Vol. 30 No. 1, pp. 127-9.
Kurtar, E. (2012), "Sera Ekolojisi Ders Notları", Ondokuz Mayıs Üniversitesi, Bafra Meslek Yüksek Okulu, Vol. 72.

Lichtenthaler, H.K. and Buschmann, C. (2001), "Chlorophylls and carotenoids: Measurement and characterization by UV-VIS spectroscopy", Current Protocols in Food Analytical Chemistry, John Wiley and Sons, USA.

Murashige, T. and Skoog, F. (1962), "A revised medium for rapid growth and bio assays with tobacco tissue cultures", Physiologia Plantarum, Vol. 15 No. 3, pp. 473-97.

Pavan, R., Jain, S. and Kumar, A. (2012), "Properties and therapeutic application of bromelain: a review", Biotechnology Research International, Vol. 2012, Article ID 976203, pp. 1-6.

Perrin, F., Brahem, M., Dubois-Laurent, C., Huet, S., Jourdan, M., Geoffriau, E., Peltier, D. and Gagné, S. (2016), "Differential pigment accumulation in carrot leaves and roots during two growing periods", Journal of Agricultural and Food Chemistry, Vol. 64 No. 4, pp. 906-912.

Prior, R.L. and Cao, G. (2000), "Analysis of botanicals and dietary supplements for antioxidant capacity: A review", Journal of AOAC International, Vol. 83 No. 4, pp. 950-6.

Ramasamy, S., Wahab, N.A., Abidin, N.Z. and Manickam, S. (2013), "Effect of extracts from Phyllanthus watsonii Airy Shaw on cell apoptosis in cultured human breast cancer MCF-7 cells", Experimental and Toxicologic Pathology, Vol. 65 No. 3, pp. 341-9.

Sahari, M.A., Boostani, F.M. and Hamidi, E.Z. (2004), "Effect of low temperature on the ascorbic acid content and quality characteristics of frozen strawberry", Food Chemistry, Vol. 86 No. 3, pp. 357-63.

Samarakoon, S., Chandola, H. and Shukla, V. (2011), "Evaluation of antioxidant potential of Amalakayas Rasayana: A polyherbal Ayurvedic formulation", International Journal of Ayurveda Research, Vol. 2 No. 1, p. 23.

Sevik, H., Guney, D., Karakas, H. and Aktar, G. (2012), "Change to amount of chlorophyll on leaves depend on insolation in some landscape plants", International Journal of Environmental Sciences, Vol. 3 No. 3, pp. 105764.

Solihah, M.A., Wan Rosli, W.I. and Nurhanan, A.R. (2012), "Phytochemicals screening and total phenolic content of Malaysian Zea mays hair extracts", International Food Research Journal, Vol. 19 No. 4, pp. 15338.

Subramanian, S., Kalpana, M. and Prasath, G. (2014), "Studies on the antidiabetic activity of Ananas comosus leaves in STZ induced diabetic rats", Der Pharmacia Lettre, Vol. 6 No. 1, pp. 190-8.

Tan, B.C., Chin, C.F. and Alderson, P. (2011), "Optimisation of plantlet regeneration from leaf and nodal derived callus of Vanilla planifolia Andrews", Plant Cell, Tissue and Organ Culture (PCTOC), Vol. 105 No. 3, pp. 457-63.

Upadhyay, A., Lama, J.P. and Tawata, S. (2013), "Utilization of pineapple waste: a review", Journal of Food Science and Technology Nepal, Vol. 6 pp. 10-8.

Van den Berg, H., Faulks, R., Granado, H.F., Hirschberg, J., Olmedilla, B., Sandmann, G., Southon, S. and Stahl, W. (2000), "The potential for the improvement of carotenoid levels in foods and the likely systemic effects", Journal of the Science of Food and Agriculture, Vol. 80 No. 7, pp. 880-912.

Wakasa, K. (1989), "Pineapple (Ananas comosus L. Merr.)", in Trees II, Springer, pp. 13-29.

Wallace, T.C. (2011), "Anthocyanins in cardiovascular disease", Advances in Nutrition: An International Review Journal, Vol. 2 No. 1, pp. 1-7.

Wu, X., Gu, L., Prior, R.L. and McKay, S. (2004), "Characterization of anthocyanins and proanthocyanidins in some cultivars of Ribes, Aronia, and Sambucus and their antioxidant capacity", Journal of Agricultural and Food Chemistry, Vol. 52 No. 26, pp. 7846-56.

Zuraida, A., Shahnadz, A.N., Harteeni, A., Roowi, S., Radziah, C.C. and Sreeramanan, S. (2013), "A novel approach for rapid micropropagation of maspine pineapple (Ananas comosus L.) shoots using liquid shake culture system", African Journal of Biotechnology, Vol. 10 No. 19, pp. 3859-66. 